\title{
Pajak dan Retribusi Daerah sebagai Penopang Otonomi Daerah Dilema terhadap Kepastian Hukum bagi Iklim Usaha
}

\author{
Devi Taurisa \\ Fakultas Hukum Universitas Indonesia \\ Email: devitaurisa@ hotmail.com
}

\begin{abstract}
The implementation of regional autonomy gives flexibility to the Regional Government to increase Regional Original Revenue (PAD) through regional taxes and local user fees. However, excessive Local Government creativity has given rise to negative access to the business climate. Business actors have complained about many illegal levies with unclear legal grounds. The 1945 Constitution has provided a constitutional basis in regulating tax matters, as well as Law No. 28 of 2009 concerning Regional Taxes and Regional Levies, however, in practice various regional regulations regarding taxes and user fees overlap with central regulations, constitute a major burden for the business world. with library research methods. The results of the study concluded that there is a need for central government intervention to reorganize the authority of tax collection and regional retribution through synchronizing policies with the central tax.
\end{abstract}

Keywords: Business Climate; Local Tax; Regional Autonomy; Regional Levy.

\begin{abstract}
ABSTRAK
Pelaksanaan otonomi daerah memberikan keleluasaan kepada Pemerintah Daerah untuk meningkatkan Pendapatan Asli Daerah (PAD) melalui pajak daerah dan retribusi daerah. Namun, kreativitas Pemerintah Daerah yang berlebihan telah menimbulkan akses negatif bagi iklim usaha. Pelaku usaha mengeluhkan banyak pungutan liar yang tidak jelas landasan hukumnya. UUD 1945 telah memberikan dasar konstitusional dalam mengatur masalah pajak, serta UU No. 28 Tahun 2009 tentang Pajak Daerah dan Retribusi Daerah,namun dalam praktiknya berbagai peraturan daerah tentang pajak dan retribusi tumpang tindih dengan peraturan pusat, merupakan beban yang besar bagi dunia usaha. Penelitian ini bertujuan untuk memberikan kepastian hukum dari ketentuan penetapan pajak dan retribusi daerah bagi pelaku usaha. Jenis penelitian yang akan dilakukan adalah yuridis normatif dengan metode penelitian kepustakaan. Hasil penelitian menyimpulkan bahwa perlu adanya intervensi pemerintah pusat untuk mengatur kembali kewenangan pemungutan pajak dan retribusi daerah melalui sinkronisasi kebijakan dengan pajak pusat.
\end{abstract}

Kata kunci : Iklim Usaha; Otonomi Daerah; Pajak Daerah; Retribusi Daerah. 


\section{Pendahuluan}

Dalam negara kesatuan Republik Indonesia, sejak awal pembentukannya telah menyatakan diri sebagai negara yang berdasarkan atas hukum (rechtsstaat), bukan atas kekuasaan belaka (machtsstaat) atau negara polisi (politiestaat), hal ini tercermin dalam Penjelasan Undang-Undang Dasar 1945. ${ }^{1}$ Sebagai negara berdasarkan hukum, tiap tindakan negara harus dapat dipertanggung jawabkan pada hukum. Konsep negara rule of law diterjemahkan sebagai supremasi hukum (supremacy of law), atau pemerintahan berdasarkan hukum. Hukum menjadi landasan pokok untuk mencapai cita-cita masyarakat yang adil dan makmur secara merata. Pada hakikatnya berprinsip bahwa kekuasaan tertinggi di suatu negara adalah berdasarkan atas hukum.

Dalam rangka meningkatkan pertumbuhan ekonomi Indonesia, peningkatan kepastian hukum dan kepastian berusaha merupakan salah satu aspek yang menjadi perhatian dari Pemerintah Indonesia. Pembangunan perekonomian nasional berdasarkan atas demokrasi ekonomi harus memberikan landasan yang kokoh bagi dunia usaha demi tercapainya keseimbangan kemajuan dan kesatuan ekonomi nasional. Dalam rangka efektivitas pelaksanaan pembangunan, diperlukan adanya pemerataan pembangunan, dan hasil-hasilnya digunakan bagi seluruh rakyat. Untuk itu menjadi tanggung jawab bersama antara pemerintah pusat dan pemerintah daerah sesuai dengan kewenangan masing-masing dalam mengurus rumah tangganya sendiri.

Perjalanan penyelenggaraan pemerintahan dan otonomi daerah sebagai tata kelola pemerintahan di Indonesia sebenarnya telah dimulai sejak tahun 1974, ditandai dengan berlakunya UU No. 5 Tahun 1974 tentang Pokok-pokok Pemerintahan Daerah. ${ }^{2}$ Namun demikian, undang-undang tersebut tidak terlaksana sebagaimana yang diharapkan. Dalam praktik yang terjadi pada masa ini adalah sistem sentralisasi, dimana kontrol dari pemerintah pusat masih dilaksanakan secara dominan dalam perencanaan ataupun implementasi pembangunan di Indonesia. Seiring dengan perubahan iklim politik, baru pada era reformasi tuntutan otonomi daerah yang lebih luas dapat terwujud ditandai dengan lahirnya UU No. 22 Tahun 1999 tentang Pemerintahan Daerah dan UU No. 25 Tahun 1999 tentang Perimbangan Keuangan antara Pemerintah Pusat dan Pemerintah Daerah (PKPD). Pada masa pemerintahan

\footnotetext{
${ }^{1}$ Samidjo, Ilmu Negara, (Bandung : Armico, 1986), hlm.152. Lihat juga :Penjelasan tentangUUD RI 1945, dalam Penjelasan Sistem Pemerintahan Negara.

${ }^{2}$ Hendra Karianga, Politik Hukum dalam Pengelolaan Keuangan Daerah, cet. 2 (Jakarta: Kencana, 2015), hlm. 66. Lihat juga : UUD 1945 pasal 18 ayat (2), bahwa UU No. 5 Tahun 1974 tentang Otonomi Daerah adalah sesuai dengan amanat UUD yang tertulis "Pemerintah daerah provinsi, daerah kabupaten, dan kota mengatur dan mengurus sendiri urusan pemerintahan menurut asas otonomi dan tugas pembantuan”.
} 
Presiden Habibie inilah usaha serius melakukan desentralisasi terwujud. ${ }^{3}$ Dalam perkembangannya undang-undang tersebut telah diganti dengan UU No. 32 Tahun 2004 tentang Pajak Daerah dan UU No. 33 Tahun 2004 tentang PKPD, kemudian menjadi UU No. 23 Tahun 2014 tentang Pemerintah Daerah dan telah mengalami perubahan kedua menjadi UU No. 9 Tahun 2015.

Perubahan paradigama penyelenggaraan pemerintahan telah terjadi dari sistem sentralisasi pemerintahan searah telah berubah ke sistem desentralisasi, dalam bentuk otonomi daerah yang nyata, luas, dan bertanggung jawab. Pemerintah daerah memiliki wewenang yang lebih besar untuk melaksanakan pembangunannya berdasarkan lokalitas yang lebih tinggi dalam upaya mensejahterakan masyarakat di daerahnya. Salah satu dampak dari kebijakan ini adalah desentralisasi fiskal ${ }^{4}$, dimana pemerintah daerah berwenang untuk mendapatkan sumber keuangan, diantaranya kewenangan memungut dan mendayagunakan pajak daerah dan retribusi daerah untuk membiayai layanan publik di wilayah lokal, membiayai penyelengaraan pemerintahan dan pembangunan untuk memantapkan otonomi daerah. Pungutan pajak merupakan kebijakan pemerintah atau kebijakan publik yang ditetapkan sebagai sebuah dokumen formal dan berlaku mengikat kehidupan bersama, maka saat itu pula kebijakan publik menjadi hukum. ${ }^{5}$ Undang-Undang Dasar 1945 Negara Republik Indonesia telah memberikan dasar konstitusional dalam mengatur masalah pajak, bahwa pengaturan pajak harus ditetapkan dengan undang-undang. Pajak maupun pungutan lain yang mempunyai kekuatan bersifat memaksa untuk kepentingan negara, namun bukanlah merupakan tujuan dari negara sehingga keberadaannya adalah sebagai sarana atau instrument guna mencapai tujuan negara. ${ }^{6}$

Berdasarkan lembaga pemungutannya, Pajak dikategorikan menjadi dua, yakni Pajak Pusat dan Pajak Daerah. Pajak Pusat diatur dalam UU No. 6 Tahun 1983 juncto UU No.16 Tahun 2009 tentang Ketentuan Umum dan Tata Cara Perpajakan (KUP - Ketentuan Umum Perpajakan), sedangkan Pajak Daerah diatur dalam UU No. 18 Tahun 1997 juncto UU No. 28 Tahun 2009 tentang Pajak Daerah dan Retribusi Daerah. Pungutan pajak daerah ditetapkan berdasarkan Peraturan Daerah (Perda), namun jenis, subjek, objek, dan tarifnya tidak boleh

\footnotetext{
${ }^{3}$ Harrys Pratama Teguh, Hukum Keuangan Negara, cet. 1 (Bandung: Pustaka Setia, 2019), hlm. 51.

${ }^{4}$ Secara umum konsep desentralisasi terdiri atas : (1) Desentralisasi Politik (Political Decentralization); (2) Desentralisasi Administratif (Administrative Decentralization); (3) Desentralisasi Fiskal (Fiscal Decentralization); (4) Desentralisasi Ekonomi (Economic or Market Decentralization). Sumber : Wikiapbn, Sebuah Ensiklopedia Kementerian Keuangan, "Desentralisasi Fiskal” http://www.wikiapbn.org/desentralisasifiskal/, diakses 24 Maret 2020.

${ }^{5}$ Tjip Ismail, “Modul 1 - Ruang Lingkup Ilmu Hukum Pajak”, hlm 3, http://www.pustaka.pustaka.ut.ac.id/lib/wpcontent/uploads/pdfmk/KHUM4407-M1.pdf, diakses 24 Maret 2020.

${ }^{6}$ Lihat Amandemen ke-tiga UUD 45 pasal 23 A.
} 
bertentangan dengan UU No. 28 Tahun 2009. Pajak daerah dibedakan menjadi pajak daerah provinsi dan pajak daerah kabupaten/kota. Terhadap penerimaan pajak provinsi akan dibagi hasilkan kepada daerah kabupaten/kota dimana pajak tersebut dipungut.

Dalam UU No. 28 Tahun 2009, pemerintah daerah dilarang untuk memungut jenis pajak selain yang ditetapkan dalam undang-undang ini. Undang-undang ini mengatur jenis pajak daerah sistem daftar tertutup (closed list), artinya daerah tidak dapat memungut pajak daerah selain yang ditentukan dalam UU tersebut. Hal ini dimaksudkan untuk memberikan kepastian hukum bagi masyarakat, memastikan bahwa pungutan pajak daerah tidak akan menurunkan perkembangan ekonomi di masyarakat. Khusus untuk retribusi daerah, undangundang ini menerapkan sistem yang semi terbuka, artinya dimungkinkan adanya tambahan jenis retribusi berdasarkan kriteria yang penetapannya diatur undang-undang. Pemberian wewenang pemungutan pajak daerah dan retribusi daerah diharapkan tidak terlalu membebani rakyat dan relatif netral terhadap fiskal nasional. Pemberian kewenangan kepada daerah untuk menetapkan tarif pajak daerah dalam batas tarif minimum dan maksimum yang ditetapkan dalam undang-undang.

Dalam perkembangannya, Komisi Pemantauan Pelaksanaan Otonomi Daerah $(\mathrm{KPPOD})^{7}$ menilai banyak terjadi tumpang tindih peraturan daerah (perda) mengenai pungutan daerah atau retribusi daerah. Perda sebagai salah satu instrumen regulasi usaha dan ukuran kebijakan pembangunan ekonomi di daerah seringkali tidak selaras dengan kebijakan pemerintah pusat maupun UU No. 28 Tahun 2009 yang menjadi payung hukum pajak daerah dan retribusi daerah. ${ }^{8}$ Bagi pelaku usaha, kepastian usaha sulit diperoleh jika regulasi kerap berbeda dan tumpang tindih terkait pungutan pajak, retribusi daerah, disamping hal-hal lain seperti perizinan usaha, tenaga kerja, dan lain-lain yang berpotensi membuat angka ketidakpastian usaha semakin tinggi. Ketidakpastian berusaha dikuatirkan akan menghambat

\footnotetext{
${ }^{7}$ Komisi Pemantauan Pelaksanaan Otonomi Daerah (KPPOD) adalah lembaga independen pelaksanaan otonomi daerah yang lahir dari pemikiran bahwa pelaksanaan otonomi daerah yang lahir sejak tanggal 1 Januari 2001 perlu dicermati terus menerus demi keberhasilannya agar terwujud keadilan dan kemakmuran rakyat di semua bagian negara. Sumber : https://id/m/wikipedia.org/wiki/Komite_Pemantauan_Pelaksanaan_Otonomi_Daerah. Diakses tanggal 24 Maret 2020.

${ }^{8}$ Kepala Biro Hukum Kementerian Dalam Negeri, Widodo Sigit Pudjianto menyatakan bahwa sejak tahun 2002 hingga 2009, terdapat 1.878 perda yang sudah dibatalkan. Sekitar 1.779 diantaranya merupakan retribusi daerah. Pada tahun 2010 terjadi pembatalan 324 perda terkait dengan pajak daerah dan retribusi daerah. Pada tahun 2011 terdapat 265 perda pajak daerah dan retribusi daerah yang dibatalkan. Sumber: KPPOD, “Aturan Pungutan Daerah Kerap Tumpang Tindih" https://www.kppod.org/berita/view?id=405, diakses 30 Maret 2020.

Disampaikan pada tanggal 20 November 2019, oleh Direktur Eksekutif KPPOD, Robert Endi Jaweng, bahwa hasil penelitian dalam studi cepat pada 6 daerah yakni, Provinsi DKI Jakarta, Kota Bogor, Depok, Kabupaten Bekasi, Kulon Progo, dan Sidoarjo ditemukan 347 perda bermasalah dari total 1.109 perda. Sumber : Ananda Muhammad Firdaus, "Ratusan Perda Terindikasi Hambat Investasi Daerah", https://www.ayobogor.com/read/2019/11/20/5066/ratusan-perda-terindikasi-hambat-investasi-daerah/, diakses 30 Maret 2020.
} 
pertumbuhan investasi di daerah, yang pada akhirnya akan mempengaruhi pendapatan bagi daerah itu sendiri dimana pendapatan hasil pajak dan retribusi merupakan komponen yang penting tidak akan memberikan masukan tidak sebagaimana yang diharapkan.

\section{Metode Penelitian}

Penelitian ini merupakan penelitian yuridis normatif, dengan metode pengumpulan data melalui studi kepustakaan (library research). ${ }^{9}$ Pengumpulan data primer merupakan bahanbahan hukum yang bersifat autoritatif, mempunyai otoritas dan mengikat, ${ }^{10}$ terdiri dari Undang-Undang Dasar Negara Republik Indonesia 1945; UU No. 28 Tahun 2009 tentang Pajak Daerah dan Retribusi Daerah; UU No. 23 Tahun 2014 tentang Pemerintahan Daerah, UU No. 33 Tahun 2014 tentang Perimbangan Keuangan antara Pemerintah Pusat dan Pemerintahan Daerah, serta peraturan perundang-undangan terkait. Data primer akan didukung oleh data sekunder, berupa yaitu bahan pustaka yang berisikan informasi tentang bahan primer, berupa buku teks, artikel jurnal, dan bahan pendukung lainnya.

Pendekatan Perundang-undangan (statute approach) dan Pendekatan Konseptual (conceptual approach) akan digunakan dalam penelitian ini. Data yang terkumpul secara komprehensif akan dianalisis secara kualitatif, dimana keseluruhan data penelitian diolah dalam proses penalaran hukum (legal reasoning). Sarana atau alat untuk menganalisis menggunakan penafsiran gramatikal dengan menafsirkan peraturan perundang-undangan untuk menjawab permasalahan yang ada, selanjutnya ditarik suatu kesimpulan dan diajukan sebagai saran. ${ }^{11}$

\section{Analisis dan Pembahasan}

\section{Perkembangan Pengaturan Pajak Daerah Dan Retribusi Daerah}

Dalam negara hukum, pada hakikatnya berprinsip bahwa kekuasaan tertinggi di suatu negara adalah berdasarkan atas hukum dan bertujuan untuk mensejahterakan rakyat untuk mencapai keadilan (welfare state). Negara tidak akan bertindak sewenang-wenang ketika memungut sebagian kekayaan rakyat, sekalipun untuk kepentingan rakyat, walaupun tidak bersifat langsung, pajak harus memberikan kontraprestasi kepada pembayar pajak. Dalam

\footnotetext{
${ }^{9}$ Soerjono Soekanto dan Sri Mamudji, Penelitian Hukum Normatif Tinjauan Singkat, ed. 1, cet.17 (Jakarta : Rajawali Pers, 2015), hlm.23. Penelitian hukum normatif tidak mengenal penelitian lapangan (field research) karena yang diteliti adalah bahan-bahan hukum sehingga dapat dikatakan sebagai library based, focusing on reading andanalysis of the primary and secondary materials, tidak mengenal adanya data.

${ }^{10}$ Ibid., hlm. 141.

${ }^{11}$ Jan Gijssels \& Mark Van Hoecke, Wat is Rechtsteorie?, Kluwer Rechtswetenschap, Antwerpen, 1982, hlm. 131, dalam Jonaedi Efendi \& Johnny Ibrahim, Metode Penelitian Hukum Normatif \& Empiris, ed. 1, cet. 2, (Jakarta: Kencana, 2016) hlm. 181-182.
} 
berbagai literature sering dijumpai istilah Taxation without representation is robbery, atau No Taxation without representation. ${ }^{12}$ Pungutan pajak bukan merupakan hal baru, mengingat sejak zaman penjajahan sudah dilakukan pungutan pajak, sekalipun istilah yang dipakai dan tujuan pungutannya berbeda denga masa sekarang ini. Dulu pungutan hanya untuk kepentingan penguasa dan kesejahteraan penjajah dengan istilah upeti atau pajak.

Politik hukum nasional mengenai pungutan pajak terdapat dalam Undang-Undang Dasar 1945 Amandemen ke-tiga Bab VII B Pasal 23A menyatakan bahwa "pajak dan pungutan lain yang bersifat memaksa diatur dengan undang-undang”. Berbeda dengan pengaturan dasar dalam UUD 1945 sebelum Amandemen, dalam pasal 23 ayat (2) dinyatakan bahwa "segala pajak untuk keperluan negara berdasarkan undang-undang". Perubahan kata berdasarkan menjadi diatur, bagi penganut aliran hukum Positivisme bermakna segala pajak dan pungutan lain apabila tidak diatur selain dengan undangundang menjadi tidak sah/inkonstitusional. ${ }^{13}$

Perubahan ketentuan Pasal 23A berdasarkan pertimbangannya adalah sesuai dengan prinsip kedaulatan rakyat, pemerintah tidak boleh memaksakan berlakunya ketentuan bersifat kewajiban material yang mengikat dan membebani rakyat tanpa disetujui terlebih dahulu oleh rakyat itu sendiri melalui wakil-wakilnya di DPR. Ketentuan ini merupakan dasar filosofi pemungutan pajak, bahwa tidak ada perpindahan kekayaan tanpa persetujuan rakyat, yang memberikan izin atas perpindahan sebagian kekayaannya kepada negara melalui proses pembuatan undang-undang dimana wakil rakyat memberi persetujuan. Sehingga setiap pajak yang dipungut negara harus berdasarkan undang-undang, tidak hanya berdasarkan Keputusan Presiden atau Peraturan Pemerintah atau peraturan-peraturan yang lebih rendah dari undang-undang.

\footnotetext{
${ }^{12}$ No taxation without representation merupakan dalil pajak di Inggris, adalah sebuah seruan dalam Perang Kemerdekaan Amerika. Selama revolusi berlangsung (sebelum terbit Magna Carta, tahun 1215) pendukung kemerdekaan Amerika Serikat memprotes kenyataan bahwa ke-13 koloni harus membayar pajak ke London, namun mereka tidak memiliki perwakilan di parlemen. Mereka menuntut hak semua orang Inggris, bahwa perwakilan yang dipilih mereka untuk duduk di parlemen dapat menarik pajak. Sumber : <https://id.m.wikipedia.org/wiki/Tolak_pajak tanpa_perwakilan_rakyat>. Tax without representation is robbery; pada tahun 1750-an, frase ini digunakan di Amerika Serikat masa revolusi, bahwa pemungutan pajak tanpa pesetujuan dewan perwakilan rakyat dalam bentuk undang-undang adalah perampokan. Sumber : https://isnan-wijarno.com/2012/03/no-taxation-without-representation/. Diakses tanggal 30 Maret 2020.

${ }_{13}$ Badan Pembinaan Hukum Nasional Kementerian Hukm dan Hak Asasi Manusia RI, Analis dan Evaluasi tentang Pajak dan Retribusi Daerah, (Jakarta: Badan Pembinaan Hukum Nasional, 2013), hlm. 8.
} 
Adapun peraturan perundangan yang berkaitan dengan pajak daerah dan retribusi daerah dapat dibagi dalam tiga fase, yakni : fase sebelum 1997; fase Pembaharuan Sistem Perpajakan Daerah (1997-2000); dan fase Era Otonomi Daerah (setelah tahun 2000). ${ }^{14}$

Tabel 1

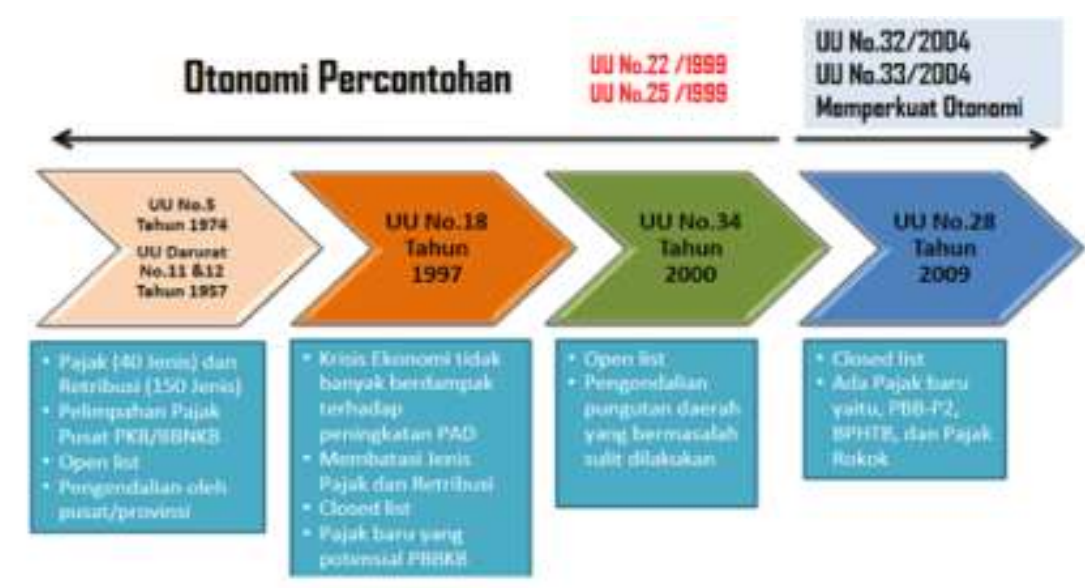

Sumiber : Duku Paiak Daerah dan Retribuni Danrah, R.D. Handak.a

\subsection{Fase Pertama (sebelum tahun 1997)}

Dalam pemerintahan yang bersifat sentralistik, peran pajak daerah pada periode ini hanya sebagai pelengkap sehingga optimalisasi pemungutan jenis pajak dan retribusi kurang mendapat perhatian. Berbagai peraturan yang terbit pada masa ini adalah Undang-Undang Darurat Republik Indonesia Nomor 11 Tahun 1957 tentang Peraturan Pajak Daerah; Undang-Undang Nomor 32 Tahun 1956 tentang Perimbangan Keuangan Negara dengan Daerah-daerah yang Berhak Mengurus Rumah Tangganya sendiri; Peraturan Pemerintah Nomor 3 Tahun 1957 tentang Penyerahan Pajak-pajak Negara kepada Daerah. Pengaturan pajak bersifat Open List. Kelemahan pada fase ini diantaranya, banyak pemungutan pajak yang tidak efisien (biaya admistrasi yang lebih tinggi dibandingkan dengan hasil pungutan), serta duplikasi atau tumpang tindih pengenaan pajak pada objek yang sama.

\subsection{Fase Kedua (Pembaharuan Sistem Perpajakan daerah; 1997-2000)}

Pembaharuan pada era ini ditujukan untuk membangun sistem pungutan daerah yang sederhana, adil, dan efektif serta mengkoreksi kelemahan-kelemahan sistem

\footnotetext{
${ }^{14}$ Ahmad Saefudin Zuhri, "Reformasi Pajak Daerah dan Retribusi Daerah", http://belajarpajakdaerah.wordpress.com/2017/10/28/reformasi-pajak-daerah-dan-retribusi-daerah/, diakses 24 maret 2020.
} 
sebelumnya. Ditandai dengan lahirnya UU No. 18 Tahun 1997 tentang Pajak Daerah dan Retribusi Daerah; Peraturan Pemerintah No. 19 Tahun 1997 tentang Pajak Daerah.

\subsection{Fase Ketiga (Era Otonomi Daerah; Setelah Tahun 2000)}

Dua aturan kebijakan fundamental lahir pada era ini, yakni UU No. 34 Tahun 2000 dan UU No. 28 Tahun 2009. Pengaturan pajak bersifat Closed List. ${ }^{15}$ Mekanisme pengawasan yang semula bersifat represif pada UU No.34 Tahun 2000, berpindah menjadi sistem preventif dan korektif pada UU No. 28 Tahun 2009.

Tabel 2. Jenis-jenis Pajak Daerah yang berlaku pada Era Otonomi Daerah:

\begin{tabular}{|c|c|c|c|}
\hline \multicolumn{2}{|c|}{ WU Fomer 34 Tahun 2000} & \multicolumn{2}{|c|}{ UU Nomor 28 Tahun 2009} \\
\hline \multicolumn{2}{|c|}{2000.2009} & \multicolumn{2}{|c|}{ 2009. sekarang } \\
\hline Paiak Provins & Paiak Kabupatan Kota & Paik Provinsi & Paiak KabupataniKata \\
\hline 1 Pajak kendaraan bermotor & 1 Pajak hotal & 1 Pajak kendaraan bem otor & 1 Pajak hotel \\
\hline 2 Bea balik nama kendaraan bemotor & 2 Pajak restoran & 2 Baa baik nama kendaraan bermotor & 2 Pạjak restoan \\
\hline $\begin{array}{l}3 \text { Pajak bahan bakar kendaran bem otor } \\
4 \text { Pajak pengambilan dan pamartastan air } \\
\text { bauah tana dan air pemkaan }\end{array}$ & $\begin{array}{l}3 \text { Pajak hiburan } \\
4 \text { Pajak rekiame }\end{array}$ & $\begin{array}{l}\text { 3. Pajak bahan bakar ke ndaran bem otor } \\
4 \text { Pajak penganbilan dan pemanfastan aif } \\
\text { basah tanah dan air pemukann }\end{array}$ & $\begin{array}{l}3 \text { Pajak hburan } \\
4 \text { Pajak reklame }\end{array}$ \\
\hline & 5 Pajak pakir & 5 Pajak rokok & 5 Pajak pakir \\
\hline & $\begin{array}{l}6 \text { Pajak penerangan jalan } \\
\text { Pajak pengambilan dan } \\
7 \text { pergolahan bahan galian } \\
\text { goiongan C }\end{array}$ & & $\begin{array}{l}6 \text { Pajak penerangan jaian } \\
7 \text { Pajak mineral bukan logam dan } \\
\text { batuan; }\end{array}$ \\
\hline & & & $\begin{array}{l}8 \text { Pajak sarang burung walet; } \\
\text { Pajak penganbian dan } \\
9 \text { pemariaatan airbaveh tanah; } \\
\text { Pajak bum dan bergunan } \\
10 \text { perdesaan dan perkotaert dan } \\
\text { Bea periehan hak atas tanah } \\
11 \text { dan bangunan }\end{array}$ \\
\hline
\end{tabular}

\section{Otonomi Daerah Sebagai Reformasi Sistem Pemerintahan Dan Implikasinya}

\section{Terhadap Desentralisasi Fiskal}

Sejak pemerintahan Republik Indonesia mulai terbentuk, konsep otonomi daerah selalu menjadi pembicaraan penting dalam berbagai perdebatan yang diselenggarakan untuk mencari konsep ideal ketatanegaraan. Otonomi daerah yang lahir dari sistem desentralisasi dianggap merupakan langkah awal dalam mewujudkan kualitas kehidupan masyarakat dan sekaligus untuk meningkatkan kemakmuran dan kesejahteraan masyarakat Indonesia. Melalui otonomi daerah diharapkan terwujud keadilan dan kemakmuran rakyat di semua bagian negara berdasarkan potensi dan keanekaragamnya tanpa meninggalkan prinsip kesatuan Republik Indoensia. Pemberian otonomi daerah dipandang dapat mempercepat terwujudnya kesejahteraan masyarakat karena efisiensi akibat penyerahan

\footnotetext{
${ }^{15}$ Lihat Pasal 2 ayat (3) UU No. 28 Tahun 2009 tentang Pajak Daerah dan Retribusi Daerah.
} 
urusan kepada pemerintah daerah dianggap mempersingkat proses dibandingkan harus dilaksanakan atau diputuskan dari pemerintah pusat. ${ }^{16}$

Otonomi Daerah dilaksanakan dalam Era Reformasi 1998, tepatnya pada tahun 1999, ditandai dengan lahirnya UU No. 20 Tahun 1999 tentang Pemerintahan Daerah dan UU No. 25 Tahun 1999 tentang Perimbangan Keuangan antara Pemerintah Pusat dan Daerah (PKPD). Otonomi di Era Reformasi menjadi jawaban persoalan otonomi daerah di Era Orde Baru yang terbukti gagal mengatasi krisis nasional yang terjadi pada tahun 1997. Pemerintahan yang sentralistis dalam penguasaan sumber daya hanya berada di tangan segelintir elite ekonomi di pusat, menghantar ekonomi Indonesia mengalami kehancuran total dengan segala implikasinya. ${ }^{17}$ Dalam perkembangannya, agar pelaksanaan otonomi daerah tidak kebablasan, pemerintah melakukan beberapa revisi pada UU No. 22 Tahun 1999, kemudian dikenal dengan UU No. 32 Tahun 2004 tentang Pemerintahan Daerah dan UU No. 33 Tahun 2004 tentang PKPD.

Dalam sistem otonomi daerah, sebagian besar keputusan dan kebijakan yang berada di daerah dapat diputuskan di daerah tanpa adanya campur tangan dari pemerintahan di pusat. Konsep desentralisasi dalam pelaksanaan otonomi daerah tidak hanya mengalihkan beban dan tanggung jawab ke daerah, tetapi juga mengalihkan berbagai wewenang dan hak-hak yang dikuasai oleh pemerintah pusat kepada pemerintah daerah. Jennie Ilene Litvack, seorang ekonom Kanada membedakan desentralisasi menjadi tiga bentuk, yakni : Desentralisasi politik; Desentralisasi administrasi; dan Desentralisasi fiskal. Pembagian ketiga desentralisasi ini pada hakikatnya tidak mengubah tujuan desentralisasi untuk kesejahteraan rakyat, tidak berdiri sendiri namun saling berkaitan satu sama lain. Konsep desentralisasi fiskal menyangkut kewenangan menggali sumber-sumber pendapatan, hak untuk menerima transfer dari pemerintahan yang lebih tinggi, dan menentukan belanja rutin maupun investasi. ${ }^{18}$ Komponen desentralisasi fiskal dapat dibagi menjadi tiga, yaitu desentralisasi pengeluaran; desentralisasi pengeluaran bangunan; dan desentralisasi penerimaan, yakni merupakan rasio antara total penerimaan Anggaran Pendapatan Belanja Daerah (APBD).

Desentralisasi fiskal di Indonesia secara garis besar dapat dibagi dalam dua era, yakni Era Desentralisasi Fiskal Terbatas, sebagaimana yang dianut oleh UU No. 5 Tahun 1974, dan Era Desentralisasi Fiskal Luas, dikenal dalam era UU No. 22 Tahun 1999.

\footnotetext{
${ }^{16}$ Abdul Manan, Peran Hukum dalam Pembangunan Ekonomi, ed. 1, cet. 3 (Jakarta: Kencana, 2018), hlm. 223.

${ }^{17}$ Hendra Karianga, Politik Hukum,cet.2, (Jakarta: Kencana, 2015), hlm. 79.

${ }^{18}$ Jennie Litvack, 1999, Decentralization, Washington: DC for World Bank, hlm. 4, dalam Ibid., hlm. 123-124.
} 
Dalam desentralisasi fiskal luas, APBD yang ditetapkan oleh pemerintah daerah cukup dengan adanya pengesahan dari Dewan Perwakilan Rakyat Daerah (DPRD), tidak perlu ada persetujuan dari tingkat pemerintah pusat. ${ }^{19}$ Dalam perkembangannya UU No. 22 Tahun 1999 digantikan oleh UU No. 32 Tahun 2004, kemudian UU No. 23 Tahun 2014.

Adanya desentralisasi fiskal memberikan peluang meningkatnya penerimaan pajak daerah, dengan basis konsumsi dan asset yang tidak bisa ditarik oleh pemerintah pusat. Efisiensi ekonomis juga terjadi karena anggaran daerah untuk pelayanan publik lebih mudah disesuaikan dengan preferensi masyarakat setempat. ${ }^{20}$ Namun disisi lain, dalam pelaksanaan desentralisasi fiskal kerapkali biaya yang harus ditanggung oleh pemerintah daerah lebih besar daripada keuntungan yang didapat, sehingga tetap mengandalkan bantuan subsidi dari pemerintah pusat. Desentralisasi fiskal dalam otonomi daerah berpotensi keluar dari kebijakan yang sebagaimana mestinya, karena sistem otonomi membuat lemah kontrol pemerintah pusat terhadap ekonomi makro, sehingga sulit untuk menerapkan kebijakan stabilitas ekonomi.

\section{Kepastian Hukum Iklim Usaha dalam Penerapan Pajak Daerah dan Retribusi Daerah}

Dalam rangka menjalankan fungsi dan kewenangan pemerintah daerah dalam bentuk pelaksanaan Pengelolaan Keuangan Daerah, maka pemerintah daerah harus mampu menggali potensi dan mengidentifikasikan sumber-sumber daya yang dimiliki. Dalam rangka meningkatkan Pendapatan Asli Daerah, pemerintah daerah harus berusaha mencari sumber-sumber keuangan daerah yang potensial, sebagian besar melalui Pajak Daerah dan Retribusi Daerah.

Pemungutan pajak merupakan kewenangan negara sebagaimana diamanatkan oleh konstitusi. Namun demikian, walaupun dapat dipaksakan harus memberikan kontraprestasi/imbalan khususnya bagi sektor pajak yang bersangkutan. Potensi pajak daerah dan retribusi daerah harus dikembangkan guna penerimaan daerah yang berkeadilan. Kebijakan pajak daerah dan retribusi daerah harus dilaksanakan berdasarkan prinsip demokrasi, pemerataan dan keadilan, melibatkan peran serta masyarakat, serta akuntabilitas dengan memperhatikan potensi daerah. ${ }^{21}$

\footnotetext{
${ }^{19}$ Ibid., hlm. 126.

${ }^{20}$ Wikiapbn, Sebuah Ensiklopedia Kementerian Keuangan, "Desentralisasi Fiskal" http://www.wikiapbn.org/desentralisasi-fiskal/, diakses 24 Maret 2020.

${ }^{21}$ Lihat Pertimbangan huruf (e) UU No. 28 Tahun 2009 tentang Pajak Daerah dan Retribusi Daerah.
} 
Pemerintah Daerah dalam melakukan pungutan pajak harus tetap menempatkan sesuai dengan fungsi pajak yakni fungsi penerimaan (budgetair) sebagai alat untuk mengisi kas negara untuk membiayai kegiatan pemerintahan dan pembangunan, dan fungsi pengaturan (regulerend), yakni bila pajak diperlukan sebagai instrument atau alat pengatur untuk mencapai tujuan, contoh pajak minuman keras dimaksudkan agar rakyat menghindari atau mengurangi konsumsi alkohol. Suatu pajak dan retribusi daerah harus memenuhi beberapa prinsip umum sehingga pemungutannya dapat dilaksanakan secara efisien dan efektif. Prinsip-prinsip pokok dari pajak yang baik diantaranya: prinsip keadilan (Equity), yakni pentingnya keseimbangan berdasarkan kemampuan masing-masing subjek pajak daerah; prinsip kepastian (Certainty),pentingnya kepastian bagi aparatur pemungut maupun wajib pajak mengenai subjek, objek, tarif dan dasar penggenaan; prinsip kemudahan (Convenience), yakni pentingnya saat dan waktu yang tepat bagi wajib pajak dalam memnuhi kewajibannya; prinsip efisiensi (Efficiency), dalam arti biaya yang dikeluarkan dalam melaksanakan pungutan tidak boleh lebih besar dari jumlah pajak yang dipungut. $^{22}$

Secara umum, pemerintah daerah dalam rangka meningkatkan pendapatan daerah melalui optimalisasi pemungutan pajak dan retribusi daerah harus melakukan berbagai cara diantaranya memperluas basis penerimaan yang dapat dipungut oleh daerah, yang dalam perhitungan ekonomi dianggap potensial. Untuk itu, pemerintah daerah harus mampu mengidentifikasikan pembayar pajak baru/potensial, jumlah pembayar pajak, memperbaiki data basis objek, memperbaiki penilaian, menghitung kapasitas penerimaan dari setiap pungutan, serta memperkuat proses pemungutan dan pengawasan pungutan. Dalam penggalian sumber-sumber keuangan yang berasal dari pajak, pemerintah daerah harus memperhatikan dasar pengenaan dan tarif pajak. Pemerintah yang cenderung menggunakan tarif setinggi-tingginya untuk memperoleh total penerimaan pajak daerah yang maksimal secara teoritis, tidak selalu berhasil dalam kenyataannya. Hal ini tergantung respon dari wajib pajak, ataupun permintaan dan penawaran barang yang dikenakan tarif pajak yang lebih tinggi.

Sistem close list yang dianut dalam UU No. 28 Tahun 2009, merupakan pembatasan jumlah jenis pajak atau retribusi daerah yang dapat diberlakukan sebagai pungutan dan dapat dipungut oleh daerah. Pembatasan ini mengandung maksud adanya kepastian hukum kepada masyarakat dan dunia usaha mengenai jenis pungutan pajak maupun retribusi yang

\footnotetext{
${ }^{22}$ Kemenkeu, "Pajak Daerah” http://www.djpk.kemenkeu.go.id/wp-content/uploads/2018/08/pajak_daerah-1.pdf, diakses 31 Maret 2020.
} 
harus mereka bayar, serta adanya jaminan bahwa tidak akan ada lagi jenis pajak atau retrubusi baru yang akan dipungut selain yang sudah ada. Sistem close list juga merupakan salah satu bentuk pengawasan terhadap pungutan pajak daerah dan retribusi daerah. ${ }^{23}$

Selain pembatasan terhadap objek pajak, pola pengawasan pemungutan pajak daerah dan retribusi daerah dilakukan secara preventif dan korektif sebagaimana ditentukan dalam UU No. 28 Tahun 2008 dilakukan melalui evaluasi suatu rancangan Rancangan Peraturan Daerah (Raperda) yang mengatur pajak dan retribusi harus mendapat persetujuan Pemerintah Pusat sebelum ditetapkan menjadi perda. Dengan pengawasan preventif, pemerintah pusat dapat memahami sejauh mana kebutuhan hukum masyarakat di daerah apakah dipaksakan atau tidak. Mekanisme evaluasi diharapkan agar semua Perda pungutan pajak daerah dan retribusi daerah dapat berjalan kondusif di tataran implementasinya.

Di tingkat daerah, implementasi pembentukan peraturan daerah tentang pajak daerah dan retribusi daerah sering bermasalah dan dibatalkan oleh pemerintah pusat. Beberapa permasalahan dalam penetapan dan pelaksanaan Perda pajak daerah dan retribusi daerah diantaranya: ${ }^{24}$ dari sisi formal, banyak pungutan daerah didasarkan pada keputusan/peraturan kepala daerah. Secara yuridis, pungutan semacam ini harus batal demi hukum sebagaimana yang diamanatkan dalam undang-undang, namun tetap dilaksanakan pemungutannya; dari sisi materiil, muatan/materi yang diatur dalam peraturan daerah tidak memenuhi sebagai diatur dalam undang-undang; ${ }^{25}$ objek pajak yang diperluas; tarif ditetapkan dengan keputusan kepala daerah; pungutan daerah yang tumpang tindih; pungutan retribusi bersifat pajak dan merintangi arus barang; masa retribusi tidak sesuai dengan masa berlakunya izin; pengenaan retribusi atas fungsi pelayanan dan perizinan yang bukan merupakan kewenangan daerah bersangkutan; pelayanan yang merupakan urusan umum pemrintahan yang seharusnya dibiayai oleh pajak; kurang memperhatikan aspek ekonomi dan kepentingan umum.

\footnotetext{
${ }^{23}$ UU No.28 Tahun 2009 tentang Pajak Daerah dan Retribusi Daerah menyatakan: Daerah dilarang memungut pajak selain Pajak sebagaimana dimaksud pada ayat (1) dan ayat (2).

${ }^{24}$ Badan Pembinaan Hukum Nasional Kementerian Hukm dan Hak Asasi Manusia RI, hlm. 23 - 25.

${ }^{25}$ Ibid., hlm. 23. Sebagai contoh, beberapa peraturan daerah hanya memuat nama dan tarif pungutan, padahal ketentuan undang-undang mensyaratkan pajak daerah minimal mencakap: nama; objek; subjek; dasar pengenaan tarif; cara penghitungan pajak; wilayah pemungutan; masa pajak; penetapan; tata cara pembayaran dan penagihan; kedaluwarsa; sanksi administratif; dan tanggal mulai berlakunya Perda. Sedangkan peraturan daerah tentang retribusi daerah sekurang-kurangnya harus mengatur mengenai: nama; objek; subjek; golongan retribusi; cara mengukur tingkat penggunaan jasa; prinsip yang dianut dalam penetapan truktur dan besarnya tarif retribusi; wilayah pemungutan; penentuan pembayaran; tempat pembayaran; angsuran dan penundaan pembayaran; sanksi administratif; penagihan; penghapusan piutang retribusi yang kedaluarsa; dan tangga; mulai berlakunya Perda.
} 
Dalam pelaksanaan otonomi daerah, kadang pemerintah daerah melakukan kreativitas yang berlebihan dan tidak terkontrol dalam pelaksanaan wewenangnya hanya untuk kepentingan golongan atau kelompok, bahkan untuk mengeruk keuntungan pribadi atau oknum. Hal tersebut dapat terjadi karena sulit untuk dikontrol oleh pemerintah di tingkat pusat. $^{26}$ Banyak pungutan daerah yang ditetapkan oleh pemerintah daerah menyebabkan ekonomi biaya tinggi, tumpang tindih dengan dengan pungutan Pusat. Pelaku usaha merasa dirugikan dan tidak mendapatkan kepastian hukum berusaha, sehingga memberikan dampak yang kurang kondusif terhadap iklim investasi. Pada akhirnya, pemberian peluang bagi daerah untuk mengenakan pungutan baru yang semula ditujukan agar dapat meningkatkan PAD untuk menutupi kebutuhan pengeluaran daerah tidak sesuai harapan.

\section{Penutup}

Amandemen Ketiga UUD 1945 pada Bab VII B Pasal 23A membawa perubahan mendasar bahwa "pajak dan pungutan lain yang bersifat memaksa diatur dengan undangundang”, membawa implikasi hukum bahwa segala pajak dan pungutan apabila tidak diatur selain dengan undang-undang menjadi tidak sah/inkonstitusional. Adapun peraturan perundangan yang berkaitan dengan Pajak Daerah dan Retribusi Daerah dapat dibagi dalam tiga fase, yakni : fase sebelum 1997; fase Pembaharuan Sistem Perpajakan Daerah (19972000); dan fase Era Otonomi Daerah (setelah tahun 2000). Pada fase Era Otonomi Daerah, pengawasan pajak bersifat Closed List, dengan mekanisme pengawasan yang semula bersifat represif menjadi sistem preventif dan korektif pada UU No. 28 Tahun 2009 tentang Pajak Daerah dan Retribusi Daerah.

Dari segi ekonomi, keuntungan desentralisasi adalah kemudahan Pemerintah Daerah untuk mengelola sumber daya alam yang dimilikinya. Pengelolaan secara maksimal akan meningkatkan pendapatan daerah dan pendapatan masyarakat setempat. Dalam melaksanakan otonomi dan penyelenggaraan pemerintahan daerah, peranan Pajak Daerah dan Retribusi Daerah sebagai salah satu sumber pendapatan daerah, merupakan komponen Pendapatan Asli Daerah (PAD). Melalui PAD, Pemerintah Daerah diharapkan mampu mendanai penyelenggaraan pemerintahan dan pembangunan daerahnya. Desentralisasi fiskal akan lebih bermakna bilamana optimalisasi sumber-sumber PAD dapat meningkatkan kemampuan

\footnotetext{
26 Parta Setiawan, "Pengertian Desentralisasi-Tujuan, Bentuk, Ciri, Dasar Hukum, Dampak, Para Ahli", https://www.gurupendidikan.co.id/pengertian-desemtralisasi/, diakses 30 Maret 2020.
} 
keuangan daerah. Walaupun UU No. 28 Tahun 2009 tentang Pajak Daerah dan Retribusi Daerah lebih menekankan fungsi budgeter daripada fungsi regulen pajak, namun secara implisit fungsi mengatur dari beberapa pajak daerah. Pengaturan dalam UU No. 28 Tahun 2009 lebih ditujukan untuk peningkatan kontribusi penerimaan pajak daerah terhadap APBD, maka fungsi pengatur dari beberapa pajak daerah belum tentu dapat memberikan dampak positif dalam kehidupan bermasyarakat di daerah.

Ditetapkannya UU No. 28 Tahun 2009 tentang Pajak Daerah dan Retribusi Daerah ditujukan untuk meningkatkan kontribusi pajak dan retribusi daerah terhadap APBD agar pemerintah daerah dapat lebih independen, tidak terlalu bergantung pada pemerintah pusat. Namun demikian, adanya pajak baru, penyesuaian tarif, dan pengaturan peruntukan belum dapat dipastikan mampu memenuhi tujuan tersebut. Potensi pajak tiap-tiap daerah berbedabeda, sementara daerah tidak dapat memungut jenis pajak daerah lain selain yang telah ditetapkan undang-undang tersebut. Pada akhirnya tidak dapat dipastikan desentralisasi fiskal dapat menguatkan atau justru melemahkan bagi pemasukan daerah. Walaupun Penerapan sistem pajak daerah yang bersifat tertutup disatu sisi cenderung mengurangi otonomi pendapatan, mengakibatkan banyak terjadi pelanggaran terhadap kriteria jenis retribusi daerah. Hal ini menunjukkan ambiguitas pemikiran para pembentuk Undang-Undang No. 28 Tahun 2009 dalam mendudukkan pajak daerah dan retribusi daerah, sehingga menciptakan ketidakpastian hukum dalam dunia usaha. Hal ini justru menciptakan iklim berusaha yang tidak kondusif, pada akhirnya melemahkan perekonomian yang berefek terhadap penurunan pendapatan daerah itu sendiri.

Pemerintah Daerah hendaknya tidak menerapkan kebijakan pungutan pajak dan retribusi daerah yang berbenturan dengan pungutan pusat, baik berupa pajak maupun bea cukai, serta tidak menciptakan duplikasi pungutan karena pada akhirnya akan mendistorsi kegiatan perekonomian. Selain mempertimbangkan kriteria-kriteria perpajakan yang berlaku secara umum, seyogyanya juga mempertimbangkan ketepatan suatu pajak sebagai pajak daerah, sehingga dapat mendukung pemberian kewenangan kepada daerah dalam rangka pembiayaan desentralisasi.

Pemerintah Pusat hendaknya melakukan pembinaan dan pengarahan secara langsung baik melalui sosialisasi, bimbingan teknis atau konsultasi regional terkait pemahaman terhadap muatan/materi pungutan daerah yang didasarkan pada keputusan/peraturan kepala daerah, namun tidak memenuhi ketentuan yang berlaku dalam UU No. 28 Tahun 2009 tentang Pajak Daerah dan Retribusi Daerah, sebagai langkah antisipasi benturan atau tumpang tindih kebijakan daerah dengan kebijakan pusat. 
Dewan Perwakilan Rakyat sebagai badan legislatif hendaknya menciptakan sinkronisasi kebijakan pemerintah pusat dan pemerintah daerah. Dalam pembahasan RUU Omnibus Law Perpajakan diharapkan tidak menghentikan konsep desentralisasi, namun dapat mendorong percepatan aktivitas investasi karena iklim usaha yang kondusif. 


\section{Buku}

\section{Daftar Pustaka}

Darussalam.et al.(2019). Era Baru Hubungan Otoritas Pajak dengan Wajib Pajak. Cet. 2. Jakarta: DDTC.

Efendi, Jonaedi \& Johnny Ibrahim. (2016). Metode Penelitian Hukum Normatif \& Empiris, ed. 1, cet. 2, Jakarta: Kencana.

Ismail, Tjip. (2018). Potret Pajak Daerah di Indonesia. Cet. 1. Jakarta: Kencana.

Karianga, Hendra. (2015). Politik Hukum dalam Pengelolaan Keuangan Daerah. Cet. 2.Jakarta: Kencana.

Kementerian Hukum dan Hak Asasi Manusia RI, Badan Pembinaan Hukum Nasional. (2013). Analis dan Evaluasi tentang Pajak dan Retribusi Daerah. Jakarta: Badan Pembinaan Hukum Nasional.

Kamus Besar Bahasa Indonesia Online

Marzuki,Peter Mahmud. (2011). Penelitian Hukum (Edisi Revisi). Cet. 7. Jakarta: Kencana.

Salim dan Erlies Septiana Nurbani. (2019). Penerapan Teori Hukum pada Penelitian Disertasi, Buku Ketiga. Cet. 4, Depok: Rajagrafindo Persada.

Samidjo. (1986). Ilmu Negara. Bandung : Armico, 1986.

Suratman dan Philips Dillah. (2013). Metode Penelitian Hukum. Cet. 1. Bandung: Alfabeta.

Soekanto, Soerjono dan Sri Mamudji. (2015). Penelitian Hukum Normatif Tinjauan Singkat. Ed. 1. Cet.17. Jakarta: Rajawali Pers.

Teguh, Harrys Pratama. (2019). Hukum Keuangan Negara. Cet. 1. Bandung: Pustaka Setia.

\section{Peraturan Perundang-undangan}

Indonesia. Undang-Undang Darurat Negara Republik Indonesia, Peraturan Pajak Daerah, UU No. 11 Tahun 1957, LN No. 56 Tahun 1957, TLN No. 1287.

. Undang-Undang Pajak Daerah dan Retribusi Daerah, UU No. 18 Tahun 1997, LN No. 41 Tahun 1997, TLN No. 3685.

. Undang-Undang Perubahan atas UU RI Nomor 18 Tahun 1997 tentang Pajak Daerah dan Retribusi Daerah, UU No.34 Tahun 2000, LN No. 246 Tahun 2000, TLN No. 4048.

Undang-Undang Pajak Daerah dan Retribusi Daerah, UU No.28 Tahun 2009, LN No. 130 Tahun 2009, TLN No. 5049.

Undang-Undang Pemerintahan Daerah, UU No. 22 Tahun 1999, LN No. 60 Tahun 1999, TLN No. 3839. 
. Undang-Undang Pemerintahan Daerah, UU No. 23 Tahun 2014, LN No. 244 Tahun 2014, TLN No. 5587.

Undang-Undang Perimbangan Keuangan antara Pemerintah Pusat dan Pemerintahan Daerah, UU No. 33 Tahun 2004, LN No. 126 Tahun 2004, TLN No. 4438.

.Peraturan Pemerintah tentang Pajak Daerah. PP No. 19 Tahun 1997.

. Peraturan Pemerintah tentang Pajak daerah. PP No. 65 Tahun 2001.

.Peraturan Pemerintah tentang Penyerahan Pajak-pajak Negara kepada Daerah. PP No. 3 Tahun 1957.

.Peraturan Pemerintah tentang Pembagian Urusan Pemerintahan antara Pemerintah, Pemerintah Provinsi dan Pemerintah Kabupaten/Kota sebagai Pengganti Peraturan Pemerintah Nomor 23 Tahun 2000. PP No. 38 Tahun 2007.

Peraturan Pemerintah tentang Retribusi Daerah. PP No. 66 Tahun 2001.

\section{Internet}

Firdaus, Ananda Muhammad, "Ratusan Perda Terindikasi Hambat Investasi Daerah", https://www.ayobogor.com/read/2019/11/20/5066/ratusan-perda-terindikasi-hambatinvestasi-daerah. Diakses 30 Maret 2020.

Ismail, Tjip, "Modul 1 - Ruang Lingkup Ilmu Hukum Pajak" http://www.pustaka.ut.ac.id/lib/wp-content/uploads/pdfmk/HKUM4407-M1.pdf. Diakses 24 Maret 2020.

KPPOD, “Aturan Pungutan Daerah Kerap Tumpang Tindih", https://www.kppod.org/berita/view?id=405. Diakses 30 Maret 2020.

Setiawan, Parta, "Pengertian Desentralisasi-Tujuan, Bentuk, Ciri, Dasar Hukum, Dampak, Para Ahli", https://www.gurupendidikan.co.id/pengertian-desemtralisasi/. Diakses 30 Maret 2020.

Wijarno, Isnan, "No Taxation without Representation", https://isnanwijarno.com/2012/03/no-taxation-without-representation/. Diakses 30 Maret 2020.

Wikiapbn, Sebuah Ensiklopedia Kementerian Keuangan, "Desentralisasi Fiskal" http://www.wikiapbn.org/desentralisasi-fiskal/. Diakses 24 Maret 2020.

Yoga Nurdiana Nugraha, (Rabu, 30 Jan 2019), "Desentralisasi dan Ketergantungan Fiskal Daerah”, $\quad$ https://m.detik.com/news/kolom/d-4406834/desentralisasi-danketergantungan-fiskal-daerah/. Diakses 24 Maret 2020.

Zuhri, Ahmad Saefudin, "Reformasi Pajak Daerah dan Retribusi Daerah", http://belajarpajakdaerah.wordpress.com/2017/10/18/reformasi-pajak-daerah-danretribusi-daerah/. Diakses 24 Maret 2020. 